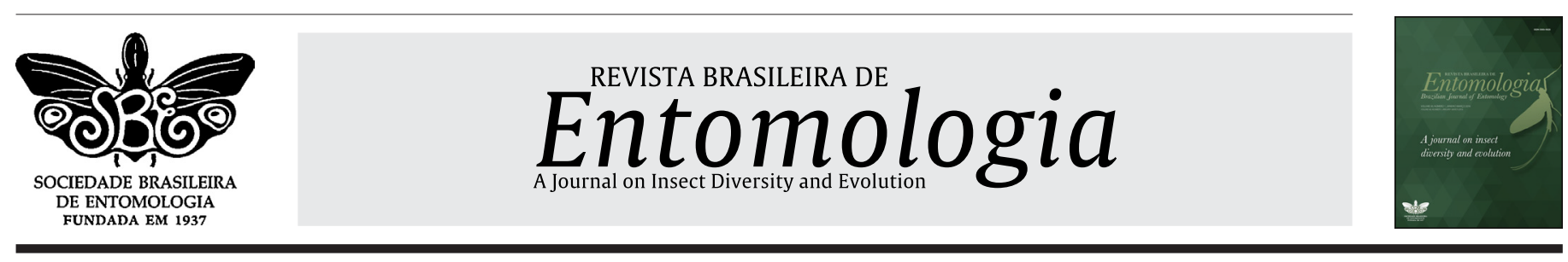

\title{
Molecular characterization and phylogenetic assessment of agricultural-related noctuids (Lepidoptera: Noctuidae) of South America
}

\author{
German San Blas ${ }^{1}$, Estela Maris Baudino², Fernando Maia Silva Dias ${ }^{3,4 *}$ (i), \\ Diego Rodrigo Dolibaina ${ }^{3}$, Alexandre Specht ${ }^{5}$ (D), Mirna Martins Casagrande ${ }^{3}$, \\ Paula Cornejo ${ }^{6}$, Walter Guillot Giraudo ${ }^{7}$, Olaf Hermann Hendrik Mielke ${ }^{3}$ (D) \\ 'Universidad Nacional de La Pampa, Instituto de Ciências de la Tierra y Ambientales de la Pampa (CONICET), Facultad de Ciencias \\ Exactas y Naturales, Santa Rosa, La Pampa, Argentina. \\ 2Universidad Nacional de La Pampa, Facultad de Agronomía, Santa Rosa, La Pampa, Argentina. \\ ${ }^{3}$ Universidade Federal do Paraná, Departamento de Zoologia, Laboratório de Estudos de Lepidoptera Neotropical, Curitiba, PR, Brasil. \\ ${ }^{4}$ Universidade Estadual de Londrina, Departamento de Biologia Animal e Vegetal, Londrina, PR, Brasil. \\ ${ }^{5}$ Embrapa Cerrados, Planaltina, DF, Brasil. \\ ${ }^{6}$ Instituto Argentino de Investigaciones de Zonas Aridas, Centro Cinentífico Tecnológico (CONICET Mendoza), Laboratorio Molecular, \\ Mendoza, Argentina. \\ ${ }^{7}$ CONICET-EEA INTA Anguil, La Pampa, Argentina.
}

\section{A R T I C L E I N F O}

\section{Article history:}

Received 1 October 2021

Accepted 13 December 2021

Available online 21 January 2022

Associate Editor: Héctor Vargas

\section{Keywords:}

Agrotis

Copitarsia

Feltia

Mythimna

Neotropical

\begin{abstract}
A B S T R A C T
Accurate identification of species is fundamental to every biological research. While morphological identification is a time-consuming and skilled technique, straightforward molecular techniques require the availability of a database of previously sequenced and identified specimens. For most countries of South America, species of noctuids with available sequences are scarce, mostly restricted to species of economic importance, making molecular identification untenable. Here we sequenced the mitochondrial DNA 'barcode' region of the cytochrome c oxidase subunit I gene of 34 specimens pertaining to 26 species of South American noctuids, 20 of these for the first time. For all species, genetic distances were higher for interspecific than for intraspecific relations, supporting the utility of DNA 'barcodes' to identify species. Larger intraspecific divergences occurred in species of Agrotis and Anicla, and interspecific divergences lower than $2 \%$ occurred in about one fifth of the species, all in species of Agrotis, Feltia, and Anicla. These results will allow identifying these species using DNA 'barcodes', either for pest management or general biological studies. Furthermore, we carried out phylogenetic analyses with those sequences and 158 other sequences of 85 species of noctuids mined from GenBank. These analyses, in every case, grouped species of the same genus suggesting that the DNA 'barcodes' region alone can be useful for lower level phylogeny in this group, recovering as monophyletic groups such as Copitarsia, Agrotis and Austrandesiita. Conversely, groups such as Mythimna (Mythimna) and the subgenera of Feltia were not recovered as monophyletic, suggesting the need for further taxonomic studies in these groups.
\end{abstract}

\section{Introduction}

Species identification is the foundation for all biological research. However, rapid and accurate species identification is not always possible, especially in highly diverse groups, as insects, and in species-rich and understudied regions, as South America. Identifying species through morphology alone takes time and skilled manpower, and it overlooks cryptic species. Molecular identification, in contrast, is a rapid tool with increasingly lower costs, and allows identification of cryptic species.

\footnotetext{
* Corresponding author.

E-mail: fernandomsdias@yahoo.com.br (F.M.S. Dias)
}

Nevertheless, there is growing evidence that both morphological and molecular methods are equally important and should be integrated to provide stronger support for delimiting and identifying species (Desalle, 2006; Padial et al., 2010; Silva-Brandão et al., 2009). Outdated taxonomy and difficulties in species identification in the field can lead to substantial problems in formulating and developing crop management, trade, and economic policies. This is particularly true for genera without recent systematic revisions or with cryptic species.

Noctuidae (Lepidoptera) includes several of the most harmful agricultural pest species of the order. Most species are included in 
a group referred to as the 'pest clade' by Mitchell et al. (2006). This clade comprises cutworms, armyworms, corn earworms, and many other pests. Despite their economic importance, many species were incorrectly identified for decades. Recent systematic studies helped to solve identity problems within genera of economic importance in South America such as Agrotis Ochsenheimer (San Blas, 2014, 2015; San Blas and Barrionuevo, 2013), Feltia Walker (Dias et al., 2017, 2018; San Blas and Agrain, 2017; San Blas et al., 2019), Leucania Ochsenheimer (Cocco et al., 2019; Dolibaina et al., 2019), and Spodoptera Guenée (Brito et al., 2019). Except for Brito et al. (2019), all these studies were based exclusively on adult morphology.

Accurate species identification of immature stages is even harder. In South America, most species with known immature stages are those with economic importance (Angulo et al., 2006), while the vast majority of other species remain unknown.

This large knowledge gap for species without economic importance and immature stages of many species, in addition to the current highly mobile globalized world, climate change, and agricultural practices changes, may lead to overlook or to delay the detection of changes in pest diversity in the future (Cannon, 1998; Zhao et al., 2011). As evidenced by the recent invasion of the Old World cotton bollworm, Helicoverpa armigera (Hübner), into the New World (e.g., Czepak et al., 2013; Tay et al., 2013), whose similarity to the New World H. zea (Boddie) was likely an important factor for its delayed detection (Specht et al., $2013,2021)$. Hence, the use of tools that help in species identification regardless of their developmental stage becomes a priority.

Molecular characterization of species proved to be an excellent tool for species identification, and the most popular sequence used for this purpose is the mitochondrial DNA 'barcode' region of the cytochrome $c$ oxidase subunit I (COI) (Hebert et al., 2003). The use of DNA 'barcodes' was originally proposed and tested for Lepidoptera (Hebert et al., 2003, 2004a) and it has been proven useful for identification of species in a wide range of taxa, from fungi (Begerow et al., 2010) to birds (Hebert et al., 2004b). DNA 'barcodes' has also been successfully used to distinguish Noctuidae pest species (Behere et al., 2008; Brito et al., 2019; Gomez-Rolim et al., 2013; Simmons and Scheffer, 2004; among many others). Nevertheless, the use of DNA 'barcodes' for species identification requires the availability of a comprehensive database of previously sequenced and correctly identified specimens.

The molecular characterization of noctuid species occurring in South America is still incipient. Only widely distributed species and species of major economic importance, such as species of Chloridea Duncan [and Westwood], Chrysodeixis Hübner, Helicoverpa Hardwick, Rachiplusia Hampson, and Spodoptera (Arneodo et al., 2015; Gomez Rolim et al., 2013; Juárez et al., 2012; Michereff-Filho et al., 2021; Specht et al., 2013) were sequenced and molecularly characterized by DNA 'barcodes'. Therefore, most of the species of noctuids endemic to South American countries, many of them distributed in very specific biomes, such as the Patagonia, Pampas, and Pantanal, are not molecularly characterized. The lack of molecular characterization makes molecular identification of most of the species occurring in these countries unattainable, with the exception of a small number of widely distributed species. The lack of a comprehensive database of sequences, in addition to the aforementioned problems with morphological identification within many genera, makes it harder to detect invasive pest or emerging new pests in the region.

This study main objective is to provide molecular characterization using DNA 'barcodes' for several species of Noctuidae of the 'pest clade' occurring in South America, with emphasis on the Argentinean and Brazilian fauna, and to evaluate the genetic distance between these species and other noctuids. Also to include these sequences in a phylogenetic analysis to assess the generic association of the species and the phylogenetic placement of genera sequenced for the first time. Ultimately, the aim is to facilitate species identification of specimens in any stage of development of many pest and several non-pest species occurring in the region, the first step to further early detection of invasive species or emerging new pest species in South America.

\section{Materials and methods}

\section{Specimens}

Thirty-four specimens corresponding to 26 species of 10 genera of the 'pest clade' were sequenced (Table 1). Of these, four specimens of different species of Leucania were collected in Brazil; the remaining specimens were collected in Argentina. The specimens deposited at the Universidad Nacional de La Pampa were captured with a Pennsylvania light trap, set with a 200w mercury vapor bulb; the other specimens were actively collected with a light sheet using the same type of light bulb. A map of collecting points is shown in Fig. 1. Sequenced noctuid species belonging to the 'pest clade' were focused on previously unsequenced species. Therefore, species of Heliothinae and Spodoptera were not newly sequenced (Arneodo et al., 2015; Juárez et al., 2012).

To confirm species identities, the genitalia of the 31 males and the 3 females were dissected, as in Lafontaine (2004) and San Blas (2014), and compared with the type material and published systematic accounts (when available) (Dolibaina et al., 2019; Franclemont, 1951; Pogue, 2014; San Blas, 2014).

Most of the species included in this work were sequenced here for the first time (Table 1), which means that no public sequences were found either in GenBank (Sayers et al., 2020) or in the International Barcode of Life Consortium (iBOL, http://www.ibol.org/). To corroborate the identification of these species and to carry out a phylogenetic analysis to access the relationships among species sequenced, 158 additional DNA 'barcode' sequences of 85 species of various genera were mined from GenBank (Table S1). Species of genera Chloridea, Helicoverpa, and Spodoptera were included in the analysis to have a representation of these genera of economic importance included in the "pest clade", even though no new sequenced specimens were added. For other mined sequences, type species of genera and subgenera (if available) of the species sequenced in this work and also of close genera were selected. As this is the first time that any species of the genera Tisagronia Köhler, Pseudoleucania Staudinger, and Pareuxoa Forbes has been sequenced, additional sequences of varied genera inside Noctuini were selected to test possible associations with these genera.

Austrandesiini was erected by Angulo and Olivares (1990) to group genera occurring mainly in the Neotropical region. Later, it was reduced to subtribe and considered to have 'primitive' character states within Agrotini (Lafontaine, 2004). Due to recent changes in Noctuoidea systematics, where Agrotini was reduced to subtribe (Lafontaine and Schmidt, 2010), Austrandesiini should be reduced to infratribe. Name suffixes in other ranks within the tribal group are not formally regulated by the International Code of Zoological Nomenclature, but do have accepted standard suffixes. As suggested by Dubois (2006), the suffix -ita is used in this work for the infratribe rank.

\section{DNA extraction and COI sequencing}

DNA was extracted from the three right legs of each specimen by grinding them with liquid nitrogen using a mortar and pestle to access the DNA material without degradation and then following the protocol described by Miller et al. (1988). A fragment of the COI gene was amplified using the generic barcode primers LepF1 (attcaaccaatcataaagatattgg) 


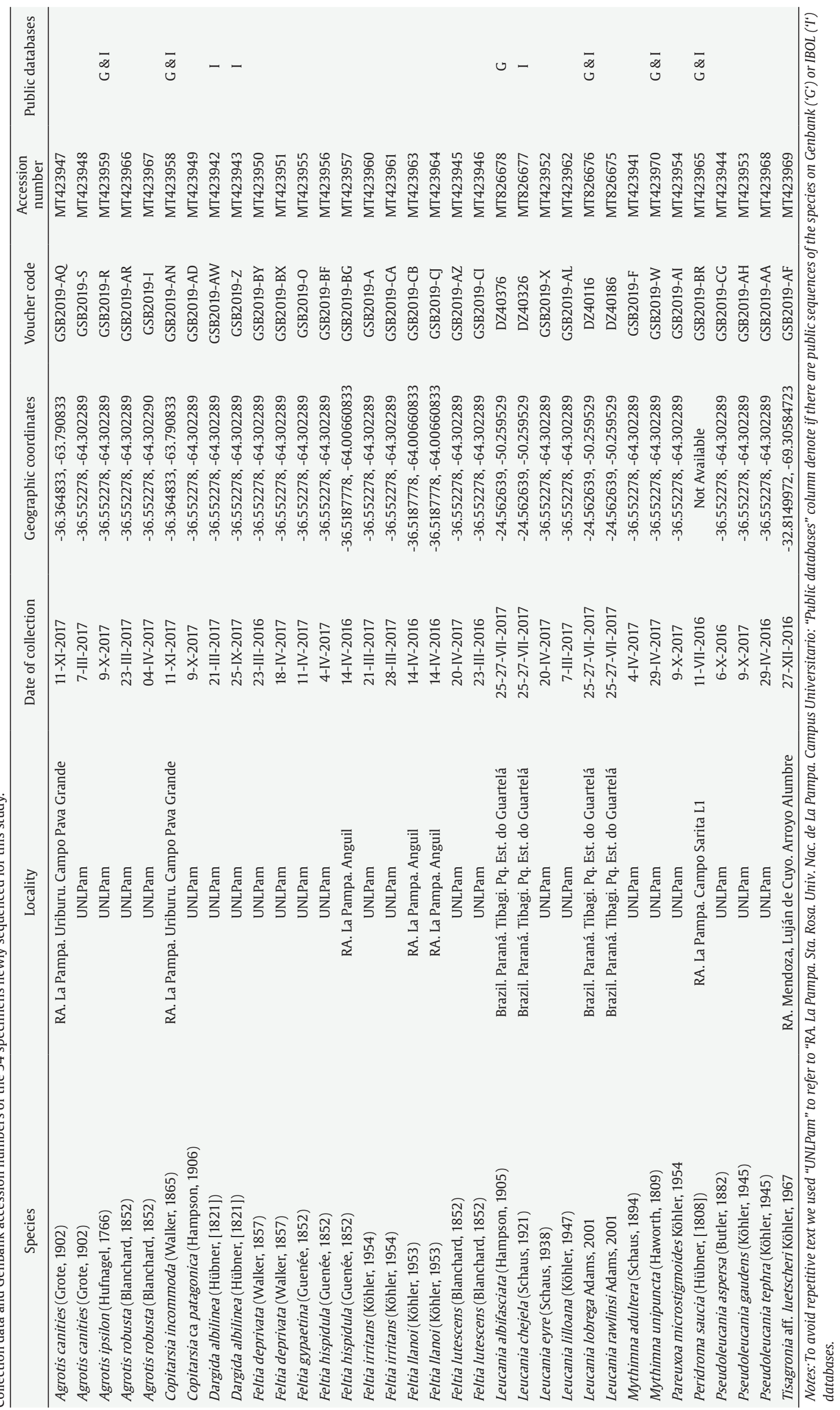




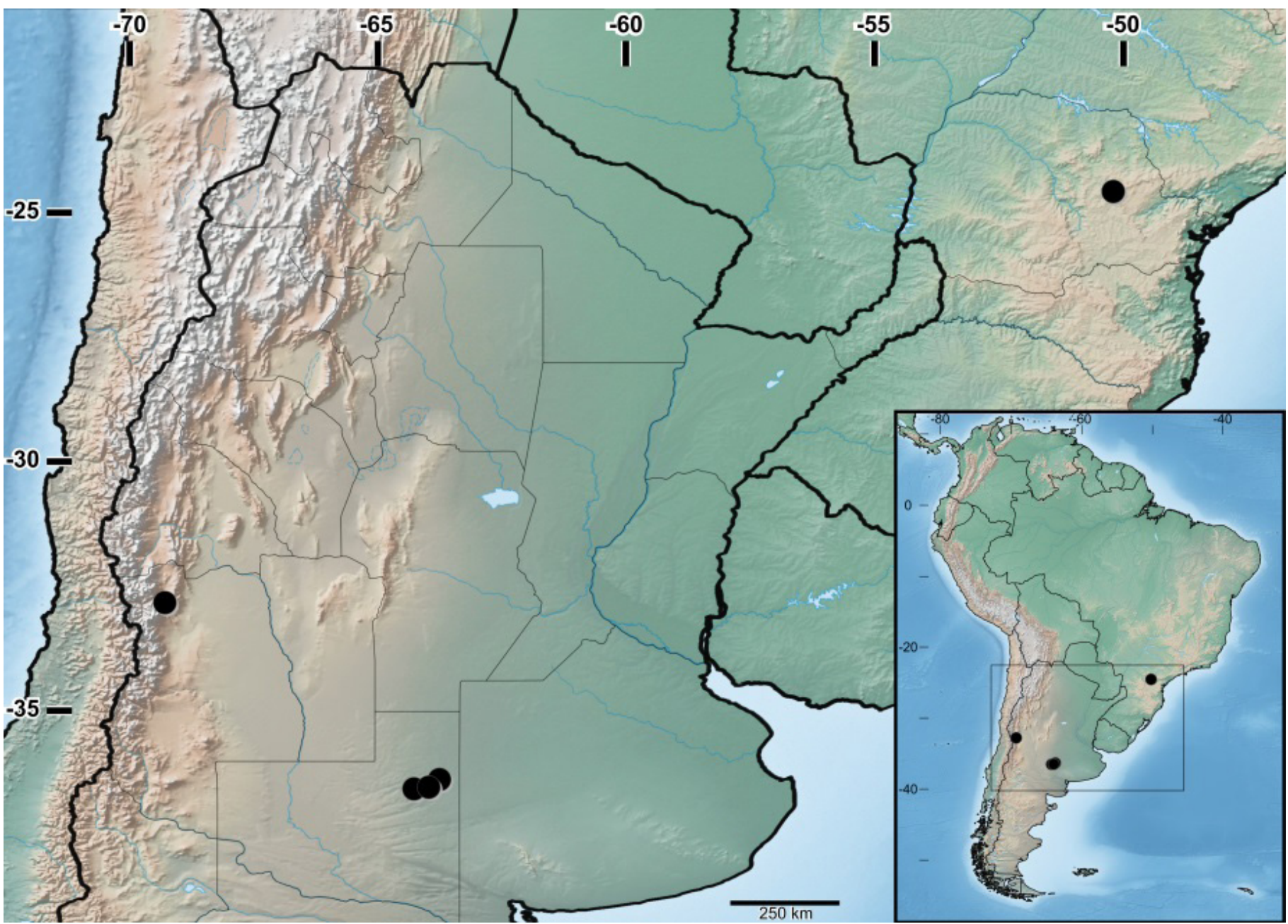

Figure 1 Collection sites in Argentina and Brazil, with provinces or states boundaries.

and LepR1 (ttaacttctggatgtccaaaaaatca). Gene amplification follows Hebert et al. (2004a).

Products were sequenced by Capillary Electrophoresis Sequencing (CES) by Macrogen Inc. (South Korea). Both directions were sequenced and compared directly to make a consensus sequence using BioEdit program (Hall et al., 2011). After assembling, products were cut to a final 658 base pair fragment of the COI gene. The same protocol was used for Brazilian Leucania specimens, performed by Helixxa (Brazil). Sequences were manually aligned using BioEdit program and submitted to GenBank.

\section{Analyses}

DNA distance was assessed using DNADist v3.5c (Felsenstein, 1993) with F84 model (Kishino and Hasegawa, 1989) as implemented in BioEdit. The data matrix was constructed with Mesquite v3.61 (Maddison and Maddison, 2019) and the phylogeny was evaluated using Equally Weighted Maximum Parsimony (MP), Maximum Likelihood (ML), and Bayesian Inference (BI). Parsimony analysis was performed in TNT v1.5 (Goloboff and Catalano, 2016; Goloboff et al., 2008) using 'New technology Search' with 'Driven search' initial level 90 and finding minimal length 500 times. Most parsimonious trees recovered were then summarized in a strict rule consensus tree, and clade robustness was evaluated using 500 replicates of Bootstrap. The best substitution model for BI and ML analyses was selected using PartitionFinder 2, with a greedy search scheme and separated 1st, 2nd, and 3rd codon positions (Lanfear et al., 2012, 2016) and JModelTest 2 (Darriba et al., 2012). jModelTest confirmed a TIM2 + $\mathrm{G}+\mathrm{I}$ model of substitution, but as it is not implemented in either MrBayes or RAxML, we instead used GTR+ G + I (Lecocq et al., 2013) which was selected as the best model by PartitionFinder. MrBayes v3.2.7a (Ronquist and Huelsenbeck, 2003) was used to reconstruct phylogenetic trees under BI with block for partition as defined by PartitionFinder. Markov chains were run for 50 million generations and sampled every 1,000 generations, with eight independent runs per analysis. The first $25 \%$ of trees were discarded as 'burnin'. RAxML-HPC v8.2.12 (Stamatakis, 2014) was used to estimate the phylogenies, with the ML + Rapid Bootstrap method and 1,000 replicates. All the analyses were performed using online versions of the software (PartitionFinder, jModelTest, RAxML, and MrBayes) on the XSEDE platform as implemented in CIPRES Science Gateway v3.3 (Miller et al., 2010). The phylograms inferred from the ML and BI analyses were displayed using FigTree v.1.4.4 (Rambaut, 2014). The aligned sequence data matrices have been deposited in TreeBase (http://purl.org/phylo/treebase/phylows/study/TB2:S26557). 


\section{Results}

\section{DNA 'barcodes'}

We obtained the DNA 'barcodes' from the 34 specimens and 158 additional sequences mined from GenBank. The sequences contained no insertions or deletions. After alignment, the sequences were composed of 658 nucleotides, 232 of which were parsimony-informative. The AT contents of the sequences was very high (70.4\%), especially at the $3 \mathrm{rd}$ codon position (93.6\%). Identification was achieved for all 26 species sequenced, either when analyzed separately or with the addition of the 85 species mined from GenBank. If we consider all the 111 species analyzed, 93.69\% (104 species) had diagnostic DNA 'barcodes' (exceptions discussed below). These results should be taken with caution due to the reduced number of samples (2 in most cases) per species analyzed.

\section{Intraspecific divergence}

Genetic distance of conspecific specimens sequenced for this study was lower than $1 \%$ in every case (Table 2 ). Furthermore, distance between all the 192 sequences and for the great majority of the specimens (91.9\% of the species) was below $1 \%$ for intraspecific variation.

Specimens of Peridroma saucia(Hübner) and Mythimna unipuncta (Haworth) sequenced for this study showed intraspecific divergence slightly higher than $1 \%$ but lower than $1.5 \%$ when compared with the mined sequences. Conspecific specimens of Agrotis gladiaria Morrison and Anicla lubricans (Guenée) also showed intraspecific divergence between $1-1.5 \%$. The four species mentioned before, with intraspecific distance between $1-1.5 \%$, corresponded to $3.6 \%$ of the total species analyzed. Intraspecific divergence between $1.5-2 \%$ was only detected in Spodoptera frugiperda specimens ( $0.9 \%$ of species). Deep intraspecific divergence $(>2 \%)$ was detected only in four species (3.6\% of the species): Agrotis munda Walker, A. obliqua (Smith), A. radians Guenée, and Anicla ignicans (Guenée).

\section{Interspecific divergence}

The genetic distance was equal or higher than $2.8 \%$ between all the species sequenced (Table 2 ). Distance between the great majority ( $79,28 \%$ of the species) of the 188 sequences analyzed was higher than $2 \%$ for interspecific variation (Table S2).

There are some exceptions to these values, the divergence between the sequenced specimen of Agrotis ipsilon (Hufnagel) and mined sequences of $A$. infusa (Boisduval) (from Australia), showed a divergence of $1.23 \%$. The three mined sequences of $A$. ipsilon showed a divergence lower than $1 \%$ with the Argentinean conspecific specimen, but higher than $1.5 \%$ with the sequences of $A$. infusa. Low interspecific divergence (1-1.5\%) was also detected between Feltia herilis (Grote), F. subgothica (Haworth), and F. tricosa (Lintner), and some pairs of specimens in other species of Feltia (Table S2). Slightly higher divergence but below $2 \%$ (medium interspecific divergence) was detected in many species of Agrotis, e.g. between Agrotis cinerea (Denis and Schiffermüller), A. gladiaria, A. rileyana Morrison, A. ripae (Hübner), A. venerabilis Walker, and $A$. vetusta (Walker), in Anicla Grote between Anicla infecta (Ochsenheimer) and A. ignicans (Guenée) and in Copitarsia Hampson between different specimens of the species of the genus. In summary, low and medium interspecific divergences accounted for the $20.72 \%$ of the species studied.

\section{Phylogeny}

Equally weighted maximum parsimony analysis resulted in 103,800 trees of 2,118 steps. Strict consensus of those trees and trees from ML and BI analyses grouped the species sequenced for this study either with conspecific specimens or with their respective congeneric species. Since relationships were mostly similar between the three analyses, only the ML tree is shown (Figs. 2 and 3), which had better resolution. Nevertheless, MP and BI trees are presented in the supporting information, as S3 and S4 respectively, and significant differences between the analyses are highlighted in the text.

Species of the genera Mythimna Ochsenheimer and Leucania Ochsenheimer were clustered together. The former was divided into two groups: one strongly supported clade comprising the species of Mythimna (Pseudaletia) Franclemont (including $M$. unipuncta, type species of Pseudaletia) and the other comprising the rest of the species of Mythimna (including M. turca(L.), type species of Mythimna) forming a polyphyletic group, with Leucania comma(L.)(type species of Leucania) nested between them in both ML and BI analyses. Leucania was recovered only in the MP analysis. The six sequenced South American species of Leucania constituted a monophyletic group, with strong support only in the BI analysis.

Copitarsia clade had strong support, but with different positions among analyses. This genus was recovered the as sister group of Noctuini in ML; inside Noctuini, sister to Euxoa Hübner in MP; and as sister to all taxa, except the outgroup, in BI. Among the species sequenced for this study, Copitarsia ca. patagonica Hampson was recovered as sister to all other species of the genus and Copitarsia incommoda (Walker) was grouped with two specimens from Argentina (EU371496-7) which Pogue and Simmons (2008) supposed to be a related to C. naenoides (Butler).

Austrandesiita was weakly supported in the ML and BI analyses. This was the first time that a gene of the genera Tisagronia, Pareuxoa, and Pseudoleucania has been sequenced; therefore, there were no congeneric sequences available to compare with. The Pareuxoa and Pseudoleucania species were grouped together.

Feltia was divided into two strongly supported clades (except for $\mathrm{MP})$, one clade with all South American species and another with North American species. The latter, separated into two low-supported clades in ML, or a polytomy in the other analyses.

Agrotis species formed a clade in all analyses (except for the inclusion of Dichagyris socorro(Barnes) in the MP), but with almost no support. Three clades were consistently recovered in all analyses: 1) Agrotis robusta (Blanchard), a Southern South American endemic species, and Agrotis apicalis Herrich-Schäffer, a Central American endemic species; 2) Agrotis ipsilon, a cosmopolitan species, and $A$. infusa, an Australasian species; and 3) A. canities (Grote), a Southern South American endemic species, and $A$. malefida Guenée, a species distributed throughout the American continent.

\section{Discussion}

Many of the most harmful species for agriculture belong to the Noctuidae and, within the family, many are grouped in what Mitchell et al. (2006) called as the 'pest clade', which was recovered as a well-supported clade in later studies (Regier et al., 2017; Zahiri et al., 2010). Even though these species are of substantial agricultural importance, their identification is often difficult. Historically, the identification of species relied on taxonomical keys or consultation with experts. Information about South American noctuids is still scarce, even though several efforts were carried out to reveal the real diversity and taxonomy of the species occurring in the continent. As a result, only few identification keys are available, most of them outdated and only including pest species of 


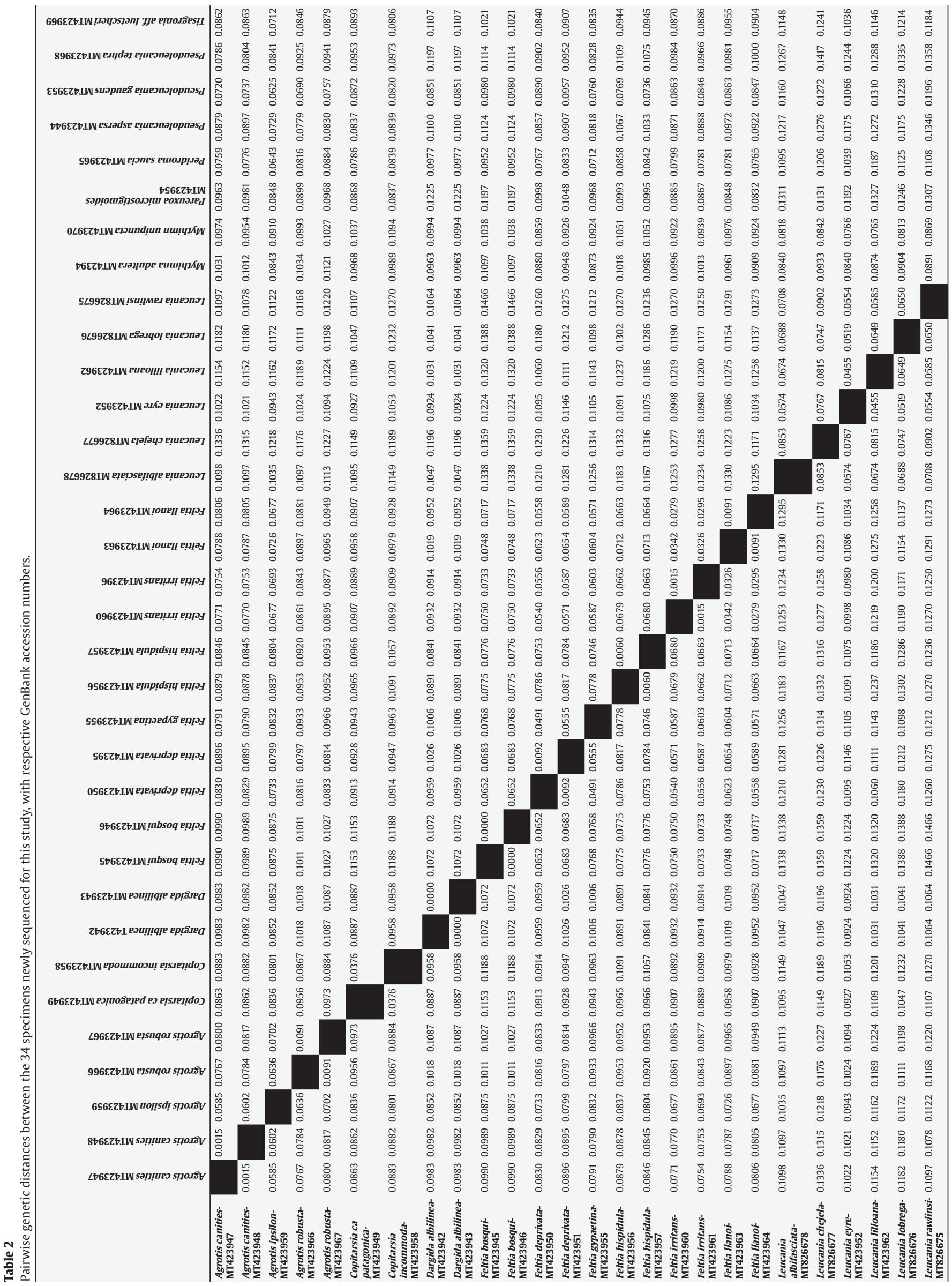




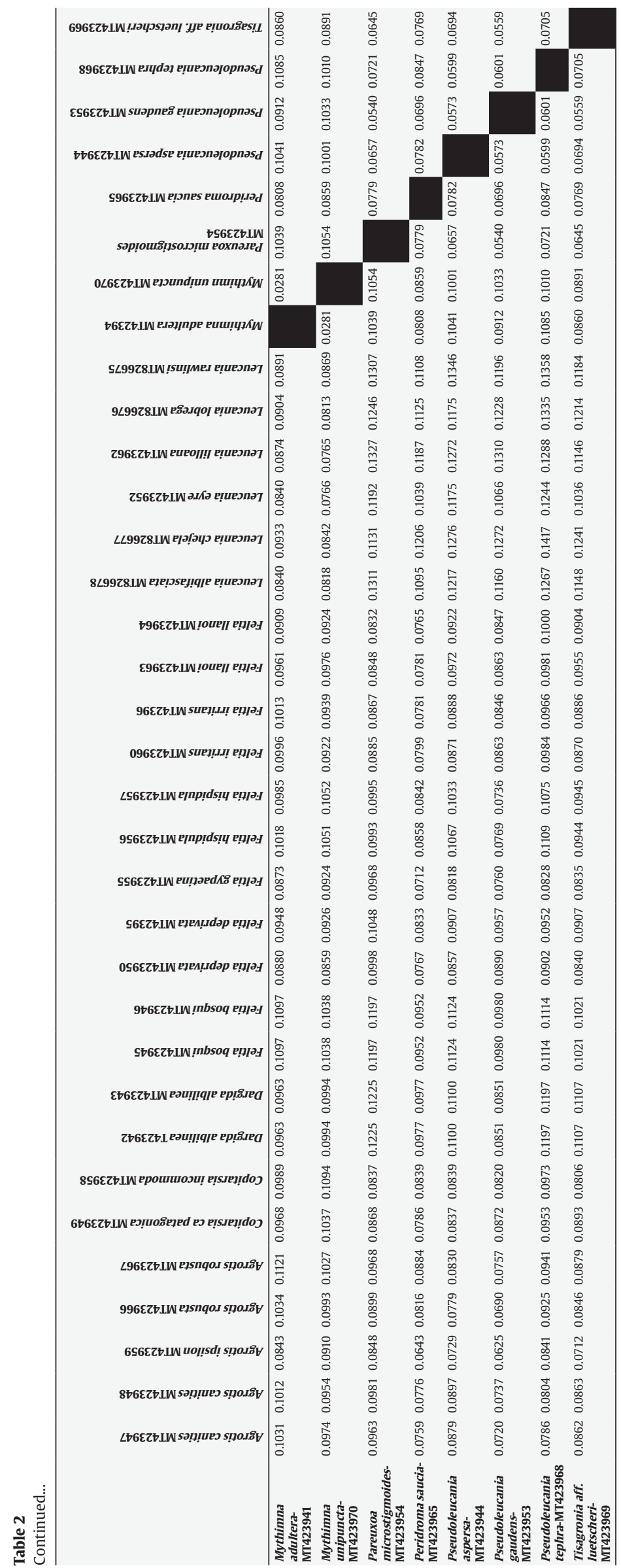




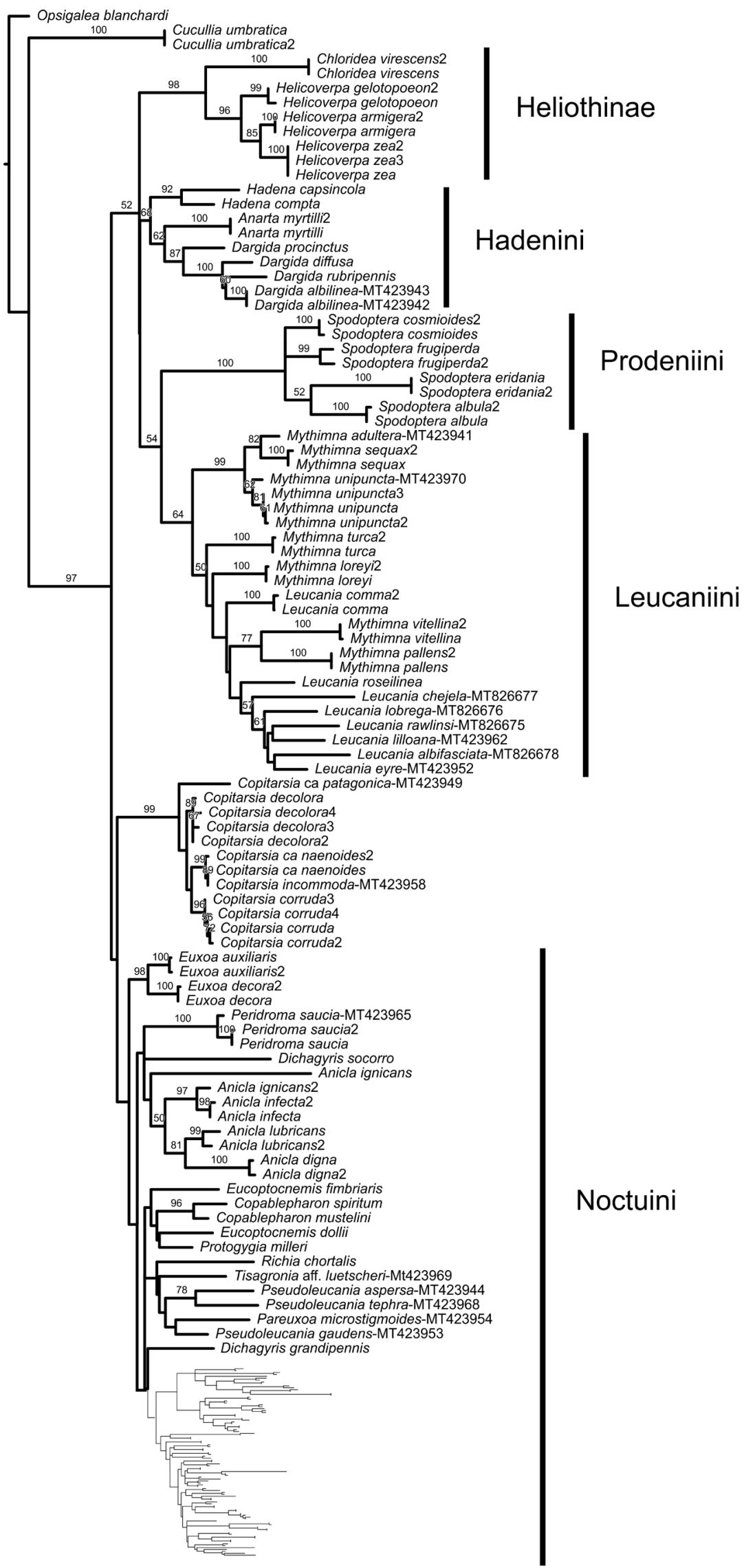

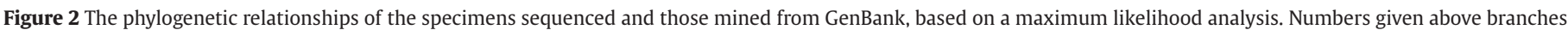
are bootstrap values $(>50 \%)$. The Feltia + Agrotis clade is shown in more detail in Fig. 3. GenBank accession numbers are provided for newly sequenced specimens. 


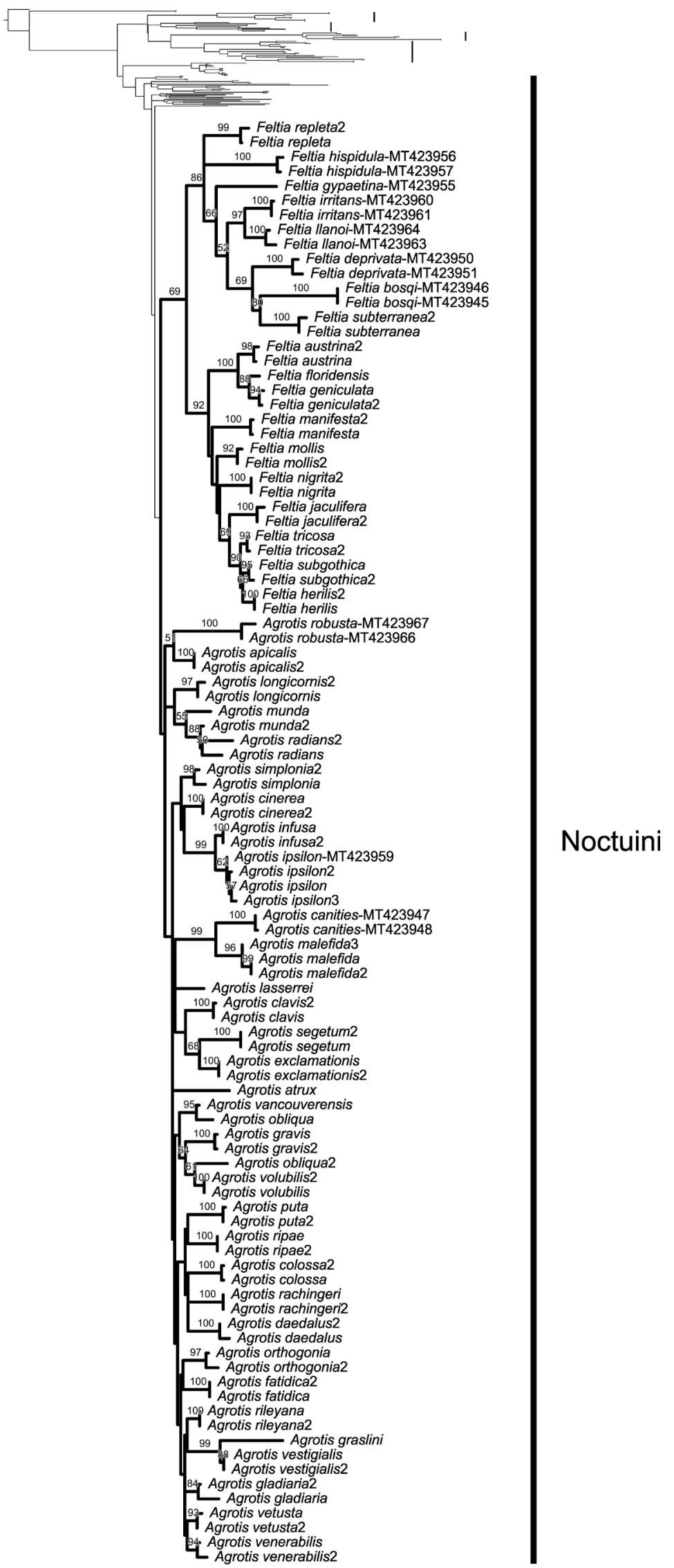

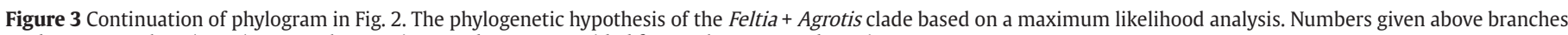
are bootstrap values ( $>50 \%$ ). GenBank accession numbers are provided for newly sequenced specimens. 
particular crops. Therefore, the identification of specimens of species without economic importance can be rather difficult. Furthermore, the identification of the immature stages of most species is nearly impossible, as identification keys are usually based on the morphology of the adult. Until we gather more information about South American noctuids, especially about their immature stages, the use of tools other than morphology for species identification is greatly justified.

\section{DNA 'barcode'}

DNA, especially the 'barcode' region of the cytochrome c oxidase subunit I, has proven to be informative for species identification in a wide range of taxa of any developmental stage (Hebert et al., 2003; Huemer et al., 2014; Zahiri et al., 2014). The present study revealed that $93.69 \%$ of the 111 noctuid species analyzed have diagnostic DNA 'barcodes'. These results supported the utility of these sequences to identify the great majority of the species studied and they corroborated our morphological delimitations. Our result is similar to those of Huemer et al. (2014) who found that $98.8 \%$ of the 1,004 Lepidoptera species studied in Finland and Austria have diagnostic DNA 'barcodes' and Zahiri et al. (2014), who recognized diagnostic DNA 'barcodes' for $90 \%$ of the 1,541 Canadian noctuoid species studied by them.

Deep intraspecific divergence $(>2 \%)$ was only detected in four species (three species of Agrotis and one of Anicla), all of them corresponding to mined sequences. Such strong divergence was detected in similar proportions in other studies (e.g. Huemer et al., 2014; Zahiri et al., 2014) and it could be associated with several causes, including taxonomic problems such as misidentifications or cryptic species. Trying to find the causes of these deep divergences requires first a detailed morphological revision of the samples to rule out possible taxonomic problems, which are inaccessible for examination.

A widely used value to distinguish species is a divergence higher than 2\% (Hebert et al., 2003; Zahiri et al., 2014). We found intraspecific divergence equal to or lower than $1 \%$ and interspecific divergence equal to or higher than $2 \%$ in the great majority of species, but there are many exceptions that would require further investigation. A divergence between 1-1.5\% was detected between samples of Agrotis gladiaria, Anicla lubricans, Peridroma saucia, and Mythimna unipuncta. The last two species correspond to specimens sequenced here and which will require further morphological and molecular studies of larger samples to unravel whether it corresponds to a high intraspecific or low interspecific divergence. Low (1-1.5\%) and medium (1.5-2\%) interspecific divergences were detected for $20.72 \%$ of the studied species, all in the species-rich Agrotis, Feltia, and Anicla. Zahiri et al. (2014) also detected DNA 'barcode' sharing and low divergences in many genera, including Feltia and Agrotis. Low interspecific divergences could be related to oversplitting of species or evolutionary factors such as recent speciation events or rapid divergence of species during a radiation accompanied by small divergences in mitochondrial DNA (Wiemers and Fiedler, 2007). Integrative taxonomy assists the delimitation of species boundaries, comprehending as many sources of data as possible, including morphological characters, reproductive compatibility, host association, and molecular characters, for example (Desalle, 2006; Padial et al., 2010; Silva-Brandão et al., 2009). Integrative taxonomy would allow a better delimitation of South American taxa, including species-rich genera such as Feltia, Mythimna, Leucania, Copitarsia, and Pseudoleucania. Morphological species delimitations are not well established for many species of these genera, especially for species endemic to South America, as most species of Austrandesiita. Evaluation of morphological and molecular delimitation of these understudied taxa would allow more accurate identifications which will in turn be a key tool in crop management, trade, and economic policies (Rubinoff, 2006).

\section{Phylogeny}

Sampling of South American specimens in phylogenetic analysis has been historically poor, with most molecular studies focused only on haplotypes and molecular characterization (Arneodo et al., 2015; Behere et al., 2008; Brito et al., 2019; Juárez et al., 2012; MichereffFilho et al., 2021; Simmons and Scheffer, 2004). This is the first time that species endemic to South America have been sequenced and analyzed in a phylogenetic context, including South American specimens of the widely distributed Peridroma saucia, Agrotis ipsilon, and Mythimna unipuncta.

In all of the analyses performed at genus and at species levels, each species is associated with other species of the same genus and the relationships between closely related genera, in most cases, are congruent with recent phylogenetic hypotheses (Fibiger and Lafontaine, 2005; Lafontaine and Schmidt, 2010). We find Mythimna (Pseudaletia) as a separate, strongly supported clade, congruent with Sutrisno (2012). Nevertheless, Mythimna (Mythimna) species do not form a monophyletic group in any of the analyses, grouped with Leucania comma in ML and BI, which cannot be compared with Sutrisno's (2012) study because he did not include any species of Leucania.

Copitarsiagenus is monophyletic in every analysis, but its position is variable: sister to the ingroup in the BI, sister to Noctuini in ML, or nested within Noctuini in MP analysis. This genus is currently considered part of the Cuculliinae, but Simmons and Scheffer (2004) mentioned that a preliminary unpublished analysis with the gene elongation factor 1-alfa indicated that Copitarsia would be phylogenetically related to Noctuinae (Noctuini as considered here). From our analyses, ML and MP agree with this relation, although weakly supported. Within Copitarsia, C. decolora (Guenée), C. corruda Pogue and Simmons, and C. incommoda form a clade corresponding to the $C$. decolora complex mentioned by Pogue (2014) and the turbata-species group (more precisely, the decolora-species group) proposed by Angulo and Olivares (2003). The Copitarsia ca. patagonica specimen sequenced here corresponds to a species in the naenoides-species group (Angulo and Olivares, 2003). This association is supported by the male genitalia characters, mainly the two longitudinal shields with recurved indentations on the dorsum of the uncus vertex and the vesical base without indented shields (Angulo and Olivares, 2003). This is the first time that a species of the naenoides-species group has been sequenced. Even though it is a single specimen, it is basal to the decolora-species group, suggesting the validity of the group, with different supports values depending on the analysis.

Austrandesiita, as originally proposed by Angulo and Olivares (1990) and herein represented by Tisagronia, Pseudoleucania and Pareuxoa, is weakly supported by ML and BI analyses. Lafontaine (2004) expanded the concept of this group to include other genera such as Peridroma Hübner and Anicla, but none of our analyses support it as such.

Feltia is consistently divided into two clades. One clade containing all South American species, which is congruent with the subterraneagroup of Feltia (Feltia) as proposed by Lafontaine (2004), and the other clade including the North American species of the genus. Lafontaine (2004) proposed two subgenera in Feltia: the nominal subgenus and Feltia (Trichosilia) Hampson, neither of them supported in the analyses. The monophyly of Feltia is congruent with Lafontaine (2004) but the subgenera proposed by him are not recovered and the subterraneagroup is consistently placed outside the Feltia (Feltia). In addition, these results are non-congruent with San Blas (2015), whose morphological phylogeny resulted in Feltia species from North and South American grouped in separated clades too, but the latter being the sister to Agrotis.

Our findings in Agrotis support the latest morphological studies which recovered Agrotis as a monophyletic group (San Blas, 2015). Furthermore, our result is congruent with systematic studies which 
considered $A$. malefida and $A$. robusta as different species (San Blas, 2014, 2015; San Blas and Barrionuevo, 2013), the former sister to $A$. canities, both closely related by morphology (San Blas, 2014, 2015), and $A$. ipsilon sister to A. infusa, a close relationship already noticed by Common (1958) due to their morphological similarity.

Molecular characterization using the DNA 'barcode' region of the COI, as demonstrated herein and in many other studies, is reliable to distinguish and identify species. This method is particularly useful for identifying poorly-known immature stages of South American species. In the current state of knowledge, the availability of a molecular database would be extremely useful in the identification of species. The advantages are its fastness, specificity, and requirement of only basic laboratory skills. Nevertheless, when the genetic distance is between $1-2 \%$, a detailed morphological study is highly recommended. On balance, molecular methods for identification of these noctuids are important when skilled taxonomists or basic taxonomic and morphological information is unavailable, as for immature stages of most species. To ease future species discovery and identification, more South American specimens and species - not only economic important ones - should be sequenced and made available in public repositories, with the objective of enlarging molecular databases for early detection of pest species and for taxonomic and biodiversity studies.

\section{Acknowledgments}

We want to thanks Florencia Campon for language corrections. We also thanks to Conselho Nacional de Desenvolvimento Científico e Tecnológico - CNPq for scientific productivity fellowships (AS 312901/2020-8, MMC 302084/2017-7 and OHHM 304849/2019-7). FMSD and DRD thanks the Coordenação de Aperfeiçoamento de Pessoal de Nível Superior - CAPES (Edital Capes-Embrapa 15/2014 - Proposta 92); FMSD also thanks the CAPES(PNPD/CAPES - PGENTO/UFPR) and CNPq (409084/2017-4) for post-doctoral fellowships.GSB thanks the Consejo Nacional de Investigaciones Científicas y Técnicas (CONICET) and the Facultad de Ciencias Exactas y Naturales (UNLPam), PC thanks the Instituto Argentino de Investigaciones de la Zonas Áridas (IADIZA, CCT-CONICET Mendoza) for providing workspace and equipment. We are also grateful to ICMBio and MMA, for the Authorizations for Scientific Activities in Brazil (SISBIO no. 48218-3 and 38547/6). This work was supported by the Agencia Nacional de Promoción Científica y Tecnológica (PICT-2016-0588 and PICT-2017-3074), Universidad Nacional de La Pampa (POIRE-2016-17), CNPq (processo n 403376/2013-0), and Embrapa (SEG MP2 02.13.14.006.00.00).

\section{Conflicts of interest}

The authors declare no conflicts of interest.

\section{Author contribution statement}

All authors contributed to the study conception and design.GSB, PC and DRD carried out data collection, molecular extraction and sequencing. All authors participated in the writing, in the manuscript reviews and approved the final version.

\section{References}

Angulo, A.O., Olivares, T.S., 1990. Austrandesiini: nueva tribu de Noctuinae australes americanos (Lepidoptera, Ditrysia: Noctuidae). Rev. Peru. Entomol. 32, 84-86.
Angulo, A.O., Olivares, T.S., 2003. Taxonomic update of the species of Copitarsia Hampson 1906, (Lepidoptera: Noctuidae: Cuculliinae). Gayana 67 (1), 33-38.

Angulo, A.O., Olivares, T.S., Weigert, G.T., 2006. Estados inmaduros de lepidópteros noctuidos de importancia económica, agrícola y forestal en Chile (Lepidoptera: Noctuidae). Universidad de Concepción, Concepción, Chile.

Arneodo, J.D., Balbi, E.I., Flores, F.M., Sciocco-Cap, A., 2015. Molecular identification of Helicoverpa armigera (Lepidoptera: Noctuidae: Heliothinae) in Argentina and development of a novel PCR-RFLP method for its rapid differentiation from H. zea and H. gelotopoeon. J. Econ. Entomol. 108 (6), 2505-2510. https://doi.org/10.1093/jee/ tov254.

Begerow, D., Nilsson, H., Unterseher, M., Maier, W., 2010. Current state and perspectives of fungal DNA barcoding and rapid identification procedures. Appl. Microbiol. Biotechnol. 87 (1), 99-108. https://doi. org/10.1007/s00253-010-2585-4.

Behere, G.T., Tay, W.T., Russell, D.A., Batterham, P., 2008. Molecular markers to discriminate among four pest species of Helicoverpa (Lepidoptera: noctuidae). Bull. Entomol. Res. 98 (6), 599-603. https:// doi.org/10.1017/S0007485308005956.

Brito, R., Specht, A., Gonçalves, G.L., Moreira, G.R.P., Carneiro, E., Santos, F.L., Roque-Specht, V.F., Mielke, O. H.H., Casagrande, M.M., 2019. Spodoptera marima: a new synonym of Spodoptera ornithogalli (Lepidoptera: Noctuidae), with notes on adult morphology, host plant use and genetic variation along its geographic range. Neotrop. Entomol. 48 (3), 433-448. https://doi.org/10.1007/s13744-018-0654-z.

Cannon, R.J., 1998. The implications of predicted climate change for insect pests in the UK, with emphasis on non-indigenous species. Glob. Change Biol. 4 (7), 785-796. https://doi.org/10.1046/j.13652486.1998.00190.x.

Cocco, J., Dolibaina, D.R., Casagrande, M.M., Specht, A., Foerster, L.A., 2019. First records of Leucania rawlinsi Adams and L. senescens Möschler (Lepidoptera: Noctuidae) in Brazil: redescription, potential association with Bt maize, larval parasitoids, and spatial and temporal distribution. Zootaxa 4604 (3), 441-460. https://doi. org/10.11646/zootaxa.4604.3.3.

Common, I.F.B., 1958. The Australian cutworms of the genus Agrotis (Lepidoptera: noctuidae). Aust. J. Zool. 6 (1), 69-88.

Czepak, C., Albernaz, K.C., Vivan, L.M., Guimarães, H.O., Carvalhais, T., 2013. First reported occurrence of Helicoverpa armigera (Hübner) (Lepidoptera: Noctuidae) in Brazil. Pesqui. Agropecu. Trop. 43 (1), 110-113. https://doi.org/10.1590/S1983-40632013000100015.

Darriba, D., Taboada, G.L., Doallo, R., Posada, D., 2012. jModelTest 2: more models, new heuristics and high-performance computing. Nat. Methods 9, 772. https://doi.org/10.1038/nmeth.2109.

Desalle, R., 2006. Species discovery versus species identification in DNA barcoding efforts: response to Rubinoff. Conserv. Biol. 20, 1545-1547. https://doi.org/10.1111/j.1523-1739.2006.00543.x.

Dias, F.M.S., Specht, A., Roque-Specht, V.F., San Blas, G., Casagrande, M.M., Mielke, O.H.H., 2018. Feltia submontana (Noctuidae, Noctuinae): redescription, taxonomy, life cycle, and spatial distribution of a neglected south american potential pest species. Neotrop. Entomol. 48, 98-110. https://doi.org/10.1007/s13744-018-0611-x.

Dias, F.M.S., Specht, A., San Blas, G., Casagrande, M.M., Mielke, O.H.H., 2017. Resurgence of a forgotten Southern Brazil endemic species: taxonomic position, redescription, and spatio-temporal distribution of Porosagrotis carolia Schaus, 1929 (Lepidoptera: Noctuidae: Noctuinae). Zootaxa 4363 (3), 421-433. https://doi.org/10.11646/ zootaxa.4363.3.7.

Dolibaina, D.R., Casagrande, M.M., Specht, A., Mielke, O.H.H., Legrain, A., Zilli, A., Goldstein, P., 2019. Taxonomy of the rivorum species-group 
of Leucania Ochsenheimer, 1816 (Lepidoptera: noctuidae). Zootaxa. 4711 (3), 545-560. https://doi.org/10.11646/zootaxa.4711.3.6.

Dubois, A., 2006. Proposed rules for the incorporation of nomina of higher-ranked zoological taxa in the International Code of Zoological Nomenclature. 2. The proposed Rules and their rationale. Zoosystema 28 (1), 165-258.

Felsenstein, J., 1993. PHYLIP Manual Version 3.5. University of Washington, Washington.

Fibiger, M., Lafontaine, J.D., 2005. A review of the higher classification of the Noctuoidea (Lepidoptera) with special reference to the Holartic fauna. Esperiana 11, 7-92.

Franclemont, J.G., 1951. The species of the Leucania unipuncta group, with a discussion of the generic names for the various segregates of Leucania in North America. Proc. Entomol. Soc. Wash. 53, 57-85.

Goloboff, P.A., Catalano, S.A., 2016. TNT version 1.5, including a full implementation of phylogenetic morphometrics. Cladistics 32, 221-238. https://doi.org/10.1111/cla.12160.

Goloboff, P.A., Farris, J.S., Nixon, K.C., 2008. TNT, a free program for phylogenetic analysis. Cladistics 24 (5), 774-786. https://doi. org/10.1111/j.1096-0031.2008.00217.x.

Gomez Rolim, A.A.S., Yano, S.A.C., Specht, A., Andrade, C.G.T.D.J., SosaGómez, D.R., 2013. Morphological and molecular characterization of the eggs of some noctuid species associated with soybean in Brazil. Ann. Entomol. Soc. Am. 106 (5), 643-651. https://doi. org/10.1603/AN13049.

Hall, T., Biosciences, I., Carlsbad, C., 2011. BioEdit: an important software for molecular biology. GERF Bull. Biosci. 2 (1), 60-61.

Hebert, P. D. N., Cywinska, A., Ball, S. L., Dewaard, J. R., 2003. Biological identifications through DNA barcodes. Proc. R. Soc. Lond. B Biol. Sci. 270 (1512), 313-321. https://doi.org/10.1098/rspb.2002.2218.

Hebert, P.D.N., Penton, E.H., Burns, J.M., Janzen, D.H., Hallwachs, W., 2004a. Ten species in one: DNA barcoding reveals cryptic species in the neotropical skipper butterfly Astraptes fulgerator. Proc. Natl. Acad. Sci. USA 101 (41), 14812-14817. https://doi.org/10.1073/ pnas.0406166101.

Hebert, P.D.N., Stoeckle, M.Y., Zemlak, T.S., Francis, C.M., 2004b. Identification of birds through DNA barcodes. PLoS Biol. 2 (10), e312. https://doi.org/10.1371/journal.pbio.0020312.

Huemer, P., Mutanen, M., Sefc, K.M., Hebert, P.D.N., 2014. Testing DNA barcode performance in 1000 species of european lepidoptera: large geographic distances have small genetic impacts. PLoS One 9 (12), e115774. https://doi.org/10.1371/journal.pone.0115774.

Juárez, M.L., Murúa, M.G., García, M.G., Ontivero, M., Vera, M.T., Vilardi, J.C., Groot, A.T., Castagnaro, A.P., Gastaminza, G., Willink, E., 2012. Host association of Spodoptera frugiperda(Lepidoptera: Noctuidae) corn and rice strains in Argentina, Brazil, and Paraguay. J. Econ. Entomol. 105 (2), 573-582. https://doi.org/10.1603/ec11184.

Kishino, H., Hasegawa, M., 1989. Evaluation of the maximum likelihood estimate of the evolutionary tree topologies from DNA sequence data, and the branching order in Hominoidea. J. Mol. Evol. 29, 170179. https://doi.org/10.1007/BF02100115.

Lafontaine, J.D. 2004. Noctuoidea: Noctuidae (Part) Agrotini (Fascicle 27:1). In: Hodges, R.W.(Ed.), The Moths of America North of Mexico. The Wedge Entomological Research Foundation, Washington, pp. $1-394$.

Lafontaine, J.D., Schmidt, B.C., 2010. Annotated check list of the Noctuoidea (Insecta, Lepidoptera) of North America north of Mexico. ZooKeys 40, 1-239. https://doi.org/10.3897/zookeys.40.414.

Lanfear, R., Calcott, B., Ho, S.Y., Guindon, S., 2012. PartitionFinder: combined selection of partitioning schemes and substitution models for phylogenetic analyses. Mol. Biol. Evol. 29 (6), 1695-1701. https:// doi.org/10.1093/molbev/mss020.
Lanfear, R., Frandsen, P.B., Wright, A.M., Senfeld, T., Calcott, B., 2016. PartitionFinder 2: new methods for selecting partitioned models of evolution for molecular and morphological phylogenetic analyses. Mol. Biol. Evol. 34 (3), 772-773. https://doi.org/10.1093/molbev/ msw260.

Lecocq, T., Vereecken, N.J., Michez, D., Dellicour, S., Lhomme, P., Valterova, I., Rasplus, J.Y., Rasmont, P., 2013. Patterns of genetic and reproductive traits differentiation in mainland vs. Corsican populations of bumblebees. PLoS One 8 (6), e65642. https://doi. org/10.1371/journal.pone.0065642.

Maddison, W.P., Maddison, D.R., 2019. Mesquite: A Modular System for Evolutionary Analysis Version 3.61. Available in: http://www. mesquiteproject.org (accessed 20 June 2021).

Michereff-Filho, M., Fonseca, M.E.N., Boiteux, L.S., Torres, J.B., Silva, K.F.A. S., Specht, A., 2021. Helicoverpa armigera Harm 1 Haplotype predominates in the Heliothinae (Lepidoptera: Noctuidae) complex infesting tomato crops in Brazil. Neotrop. Entomol. 50, 258-268. https://doi.org/10.1007/s13744-020-00845-z.

Miller, M.A., Pfeiffer, W., Schwartz, T., 2010. Creating the CIPRES science gateway for inference of large phylogenetic trees. In: Gateway Computing Environments Workshop. Proceedings. New Orleans, LA. New Orleans: IEEE, pp. 1-8. https://doi.org/10.1109/GCE.2010.5676129

Miller, S.A., Dykes, D.D., Polesky, H.F., 1988. A simple salting out procedure for extracting DNA from human nucleated cells. Nucleic Acids Res. 16 (3), 1215. https://dx.doi.org/10.1093\%2Fnar\%2F16.3.1215

Mitchell, A., Mitter, C., Regier, J.C., 2006. Systematics and evolution of the cutworm moths (Lepidoptera: Noctuidae): evidence from two protein-coding nuclear genes. Syst. Entomol. 31, 21-46. https://doi. org/10.1111/j.1365-3113.2005.00306.x.

Padial, J.M., Miralles, A., De La Riva, I., Vences, M., 2010. The integrative future of taxonomy. Front. Zool. 7 (16), 1-14. https://doi. org/10.1186/1742-9994-7-16.

Pogue, M.G., 2014. A review of the Copitarsia decolora (Guenée) (Lepidoptera: Noctuidae) species complex with the description of a new species from Chile and Argentina. Neotrop. Entomol. 43 (2), 143-153. https://doi.org/10.1007/s13744-013-0190-9.

Pogue, M.G., Simmons, R.B., 2008. A new pest species of Copitarsia (Lepidoptera: Noctuidae) from the neotropical region feeding on Asparagus and cut flowers. Ann. Entomol. Soc. Am. 101 (4), 743-762. https://doi.org/10.1603/0013-8746(2008)101[743:ANPSOC]2.0.CO;2.

Rambaut, A. 2014. FigTree Version 1.4.2. Available in: http://tree.bio. ed.ac.uk/software/figtree/ (accessed 20 June 2021).

Regier, J.C., Mitter, C., Mitter, K., Cummings, M.P., Bazinet, A.L., Hallwachs, W., Janzen, D.H., Zwick, A., 2017. Further progress on the phylogeny of Noctuoidea (Insecta: Lepidoptera) using an expanded gene sample. Syst. Entomol. 42 (1), 82-93. https://doi.org/10.1111/syen.12199.

Ro n quist, F., H u e l s e n b e c k, J ., 2003. MrBayes3:Bayesianphylogeneticinferenceundermixedmodels. Bioinformatics 19, 1572-1574. https://doi.org/10.1093/bioinformatics/ btg180.

Rubinoff, D., 2006. Utility of mitochondrial DNA barcodes in species conservation. Conserv. Biol. 20 (4), 1026-1033.

San Blas, G., 2014. Agrotis Ochsenheimer (Lepidoptera. Noctuidae): a systematic analysis of South American species. Zootaxa 3771 (1), 1-64. https://doi.org/10.11646/zootaxa.3771.1.1.

San Blas, G., 2015. A morphological phylogeny of Agrotis Ochsenheimer (Lepidoptera, Noctuidae), with emphasis on the South American species. Zool. Scr. 44 (2), 153-164. https://doi.org/10.1111/zsc.12091.

San Blas, G., Agrain, F., 2017. Revalidation and redescription of Feltia deprivata(Walker) (= bilitura of authors) (Lepidoptera: Noctuidae), a pest species on South America. Zootaxa 4323 (2), 250-260. https:// doi.org/10.11646/zootaxa.4323.2.8. 
San Blas, G., Barrionuevo, M.J., 2013. Status and redescription of the South American pest species Agrotis robusta(Lepidoptera. Noctuidae), a history of misidentifications. Rev. Mex. Biodivers. 84 (4), 1153-1158. https://doi.org/10.7550/rmb.36317.

San Blas, G., Dias, F.M.S., Specht, A., Casagrande, M.M., Mielke, O.H.H., 2019. Overlooked South American noctuid species: revalidation of Feltia Ilanoi stat. rev. and redescription of Feltia brachystria (Lepidoptera: Noctuidae). Neotrop. Entomol. 48, 614-627. https:// doi.org/10.1007/s13744-018-00668-z.

Sayers, E.W., Beck, J., Brister, J.R., Bolton, E.E., Canese, K., Comeau, D.C., Funk, K., Ketter, A., Kim, S., Kimchi, A., Kitts, P.A., 2020. Database resources of the national center for biotechnology information. Nucleic Acids Res. 48 (D1), D9-D16. https://doi.org/10.1093/nar/ gkz899.

Silva-Brandão, K.L., Lyra, M.L., Freitas, A.V., 2009. Barcoding Lepidoptera: current situation and perspectives on the usefulness of a contentious technique. Neotrop. Entomol.38(4), 441-451. https://doi.org/10.1590/ S1519-566X2009000400001.

Simmons, R.B., Scheffer, S.J., 2004. Evidence of cryptic species within the pest Copitarsia decolora (Guenée)(Lepidoptera: noctuidae). Ann. Entomol. Soc. Am. 97 (4), 675-680. https://doi.org/10.1603/00138746(2004)097[0675:EOCSWT]2.0.CO;2.

Specht, A., Sosa-Gómez, D.R., Paula-Moraes, S.V.D., Yano, S.A.C., 2013. Morphological and molecular identification of Helicoverpa armigera (Lepidoptera: Noctuidae) and expansion of its occurrence record in Brazil. Pesqui. Agropecu. Bras. 48 (6), 689-692. https://doi. org/10.1590/S0100-204X2013000600015.

Specht, A., Sosa-Gómez, D.R., Rios, D.A.M., Paula-Moraes, S.V., Malaquias, J.V., Silva, F.A.M., Roque-Specht, V.F., 2021. Helicoverpa armigera (Hübner) (Lepidoptera: Noctuidae) in Brazil: the big outbreak monitored by light traps. Neotrop. Entomol. 50 (1), 53-67. https:// doi.org/10.1007/s13744-020-00836-0.

Stamatakis, A., 2014. RAxML version 8: a tool for phylogenetic analysis and post-analysis of large phylogenies. Bioinformatics 30 (9), 13121313. https://doi.org/10.1093/bioinformatics/btu033.

Sutrisno, H., 2012. Molecular phylogeny of Indonesian armyworm Mythimna Guenée (Lepidoptera: Noctuidae: Hadeninae) based on COI gene sequences. Hayati J. Biosci. 19 (2), 65-72. https://doi. org/10.4308/hjb.19.2.65.

Tay, W.T., Soria, M.F., Walsh, T., Thomazoni, D., Silvie, P., Behere, G.T., Anderson, C., Downes, S., 2013. A brave new world for an old world pest: Helicoverpa armigera (Lepidoptera: Noctuidae) in Brazil. PLoS One 8 (11), e80134. https://doi.org/10.1371/journal.pone.0080134.

Wiemers, M., Fiedler, K., 2007. Does the DNA barcoding gap exist? a case study in blue butterflies (Lepidoptera: lycaenidae). Front. Zool. 4 (1), 8. https://doi.org/10.1186/1742-9994-4-8.

Zahiri, R., Kitching, I. J., Lafontaine, J.D., Mutanen, M., Kaila, L., Holloway, J.D., Wahlberg, N., 2010. A new molecular phylogeny offers hope for a stable family level classification of the Noctuoidea (Lepidoptera).Zool. Scr. 40 (2), 1-16. https://doi.org/10.1111/j.1463-6409.2010.00459.x.

Zahiri, R., Lafontaine, J.D., Schmidt, B.C., Dewaard, J.R., Zakharov, E.V., Hebert, P.D., 2014. A transcontinental challenge: a test of DNA barcode performance for 1,541 species of Canadian Noctuoidea (Lepidoptera). PLoS One 9 (3), e92797. https://doi.org/10.1371/ journal.pone.0092797.

Zhao, J.H., Ho, P., Azad, H., 2011. Benefits of Bt cotton counterbalanced by secondary pests? Perceptions of ecological change in China. Environ. Monit. Assess. 173 (1-4), 985-994. https://doi.org/10.1007/ s10661-010-1439-y. 


\section{Supplementary material}

The following online material is available for this article:

Table S1 - Collection data and accession numbers of sequences mined from GenBank.

Table S2 - Pairwise genetic distances between all 192 sequences analyzed in this study.

Figure S3 - The phylogenetic relationships of newly sequenced specimens and sequences mined from GenBank, based on an equally weighted maximum parsimony analysis. Numbers given above branches are bootstrap values $(>50 \%)$.

Figure S4 - The phylogenetic relationships of newly sequenced specimens and sequences mined from GenBank, based on a Bayesian inference analysis. Numbers given above branches are bootstrap values ( $>50 \%)$. 